DutTa, S. K., Jones, A. S. \& StaCey, M. (1956). J. gen. Microbiol. 14, 160-166

\title{
The Nucleic Acids of Sarcina lutea
}

\author{
By S. K. DUTTA, A. S. JONES AND M. STACEY \\ Chemistry Department, The University, Edgbaston, Birmingham, 15
}

SUMMARY: The deoxypentosenucleic acid (DNA) and pentosenucleic acid (PNA) were isolated from Sarcina lutea and their purine and pyrimidine contents determined. No differences were detected in composition of either the DNA or the PNA isolated from cultures grown at different times. The composition of the DNA from a streptomycin-resistant strain did not differ significantly from that of DNA from a normal streptomycin-sensitive strain, but the composition of the PNA from the resistant strain did differ significantly from that of PNA from the sensitive strain. The DNA contained a very high proportion of guanine and cytosine to adenine and thymine. In the PNA from both streptomycin-sensitive and resistant strains, guanine and cytosine predominated and the ratio of guanine + uracil to adenine + cytosine was nearly 1 .

Considerable information has been obtained concerning the amount of nucleic acid present in bacteria at different stages of growth (Caldwell \& Hinshelwood, 1950; Malmgren \& Hedén, 1947; Fish, Asimor \& Walker, 1950). In view of the active metabolic role of these substances and their demonstrated heterogeneity (Brown \& Watson, 1953; Chargaff, Crampton \& Lipshitz, 1953; Crosbie, Smellie \& Davidson, 1953) it appears that changes in composition, as well as amount, may occur at different growth times, particularly with pentosenucleic acid (PNA). Also, considering the association of deoxypentosenucleic acid (DNA) with the transference of resistance to antibiotics (Hotchkiss, 1951; Alexander \& Leidy, 1953) and of both PNA and DNA with the formation of certain enzyme systems (Gale \& Folkes, 1955), a difference in composition of the nucleic acids from an antibiotic-resistant strain as compared with that of the nucleic acids from a sensitive strain, appears possible. To determine whether such differences occur in Sarcina lutea, the nucleic acids were isolated, separated into DNA and PNA and their purine and pyrimidine compositions determined. The compositions of nucleic acids from organisms grown for different times were compared, and those of nucleic acids from a normal streptomycin-sensitive strain compared with those of nucleic acids from a strain which had been trained to grow in the presence of streptomycin.

\section{METHODS}

The growth of Sarcina lutea. The organism was grown in liquid medium prepared as follows: a solution containing Oxoid bacteriological peptone ( $1 \%$ ), Lab Lemco ( $1 \%$ ) and sodium chloride $(0.5 \%)$ was adjusted to $\mathrm{pH} 9$ and autoclaved at $10 \mathrm{lb} . / \mathrm{sq} . \mathrm{in}$. for $20 \mathrm{~min}$. The resulting precipitate was filtered off, the filtrate adjusted to $\mathrm{pH} 7$ and re-sterilized. Glucose $(50 \%, \mathrm{w} / \mathrm{v}$, aqueous solution) was added aseptically so that the final glucose concentration 
was $1 \%$. This medium gave a much better growth than that which had not been precipitated at $\mathrm{pH}$. The organism was grown in 81 . batches with aeration and vigorous stirring. For the preliminary work, growth was allowed to proceed at $37^{\circ}$ for $48 \mathrm{hr}$. For comparison of the nucleic acids from organisms grown for different periods, organisms were harvested in the lag, logarithmic and stationary phases. Determination of the growth curves showed that the lag phase was 7-8 hr. and that the stationary phase began after about $90 \mathrm{hr}$.

Streptomycin-resistant strain of Sarcina lutea. The original strain of Sarcina lutea was susceptible to $1 / 16,000$ streptomycin. By subcultivation in the presence of gradually increasing concentrations of the antibiotic, a strain was obtained which would grow in 1/500 streptomycin. The morphology of the organism was unchanged and it stained Gram-positive. It retained its resistance after numerous subcultures. For the isolation of the nucleic acids the organism was grown on medium with the same composition as that used for growth of the original streptomycin-sensitive strain.

Nitrogen was estimated by the method of Ma \& Zuazaga (1942), and phosphorus by the method of Jones, Lee \& Peacocke (1951).

Nucleic acid content. The nucleic acid content of Sarcina lutea was measured by the methods of Schmidt \& Thannhauser (1945) and of Schneider (1945). In the latter method, DNA was measured by the diphenylamine colour reaction (Dische, 1930) and PNA by the phloroglucinol method of Euler \& Hahn (1946).

Purine and pyrimidine content of the nucleic acids. The nucleic acids were analysed by acid hydrolysis followed by paper chromatography using the solvents of Laland, Overend \& Webb (1952) and Wyatt (1951). For both PNA and DNA trifluoroacetic acid at $155^{\circ}$ was used as the hydrolysing agent. The time of hydrolysis was $60 \mathrm{~min}$. for DNA and $80 \mathrm{~min}$. for PNA. This reagent was better than formic acid for the hydrolysis of DNA in that much less pressure was developed in the sealed tubes and the spots dried on the paper more quickly. It was better than perchloric acid for the hydrolysis of PNA because trifluoroacetic acid did not char the paper and effected complete hydrolysis of cytidylic acid without significant deamination (cf. Crosbie $e t$ al. 1953).

\section{RESULTS}

The nucleic acid content of Sarcina lutea

Sarcina lutea, which had been washed several times with distilled water and then freeze-dried, was used for the analysis. By the method of Schmidt \& Thannhauser (1945) it was found that the organism contained $9.0 \%$ nucleic acid (assuming that the nucleic acid contained $8 \%$ phosphorus, the approximate value found for samples of Sarcina lutea DNA), of which $78 \%$ was PNA and $22 \%$ DNA. By the Schneider (1945) method, a total nucleic acid content of $8.5 \%$ was found, of which $81 \%$ was PNA and $19 \%$ DNA (using purified samples of sarcina PNA and DNA as standards). It was considered that both these methods were only approximate, but in view of the possible presence of other phosphorus-containing compounds in the cell which interfere with the 
Schmidt \& Thannhauser method (Mitchell \& Moyle, 1954), the lower result, i.e. that obtained by the Schneider method, was taken as being the more accurate.

\section{Isolation of the nucleic acids of Sarcina lutea}

The nucleic acids were then isolated from a sample of the same batch of organisms (not freeze-dried) by the method already described (Jones, 1953; Dutta, Jones \& Stacey, 1953). The organisms were disintegrated by shaking with ballotini glass balls at $0^{\circ}$ for $3-4 \mathrm{hr}$., extracted with dilute sodium arsenate $(0.01 \mathrm{M})$ at $0^{\circ}$ and $\mathrm{pH} \mathbf{7 - 7 \cdot 5}$, then debris was removed by centrifuging and the nucleoproteins precipitated by the addition of cetrimide (cetyltrimethylammonium bromide, Cetavlon, I.C.I. Pharmaceuticals Ltd., Manchester). The nucleoprotein + cetrimide complex was purified by repeated

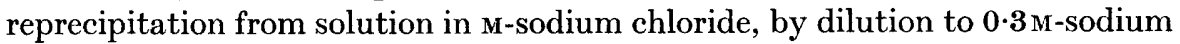
chloride, with water. The nucleoproteins were then deproteinized by shaking repeatedly with chloroform and octanol $(9: 1$; Sevag, 1934) and the nucleic acids further purified via their cetrimide salts and finally by precipitation with $20 \%(\mathrm{v} / \mathrm{v})$ ethanol in water in the presence of $0.1 \mathrm{M}$-calcium chloride. By this method a yield of $6.5 \%$ total nucleic acids was obtained.

The loss of nucleic acid during the isolation may have been due to several factors, namely: (i) loss during cetrimide precipitation and subsequent reprecipitation; (ii) adsorption of nucleic acid on the gels formed during deproteinization by shaking with chloroform and octanol; (iii) loss during the final purification procedure for the removal of polysaccharides; (iv) incomplete disintegration and extraction of the organisms; (v) enzymic degradation. Certain of these possible sources of loss were examined.

\section{Cetrimide precipitation of the nucleoproteins of Sarcina lutea}

Sarcina lutea was disintegrated by shaking with glass beads, extracted with dilute sodium arsenate $(\mathrm{pH} 7-7 \cdot 5)$ at $0^{\circ}$ and the suspension centrifuged at $20,000 \mathrm{~g}$ until the supernatant liquid became almost clear (nucleoprotein solution). Samples of this solution were treated with various concentrations of cetrimide $(0-2 \%)$, and the nucleic acids which remained in the supernatant liquids after centrifugation were precipitated with cold trichloroacetic acid and estimated by the method of Schmidt \& Thannhauser.

For the precipitation of the nucleoproteins there was an optimum concentration of cetrimide (Table 1 ) and provided that this optimum was determined there would be little loss $(c .2 \%)$ of nucleic acid in the supernatant liquid. Losses during the purification of the nucleoprotein-cetrimide complex were negligible.

A major source of loss of nucleic acid was in the chloroform + protein gels formed during deproteinization. This nucleic acid was recovered by repeatedly extracting the gels with $\mathrm{M}$-sodium chloride and purifying the recovered nucleic acid in the usual way. This brought the recovery of nucleic acid to about $92 \%$ of the total contained in the organisms. The other source of loss was during the final purification of the nucleic acids. By precipitating only 
once with cetrimide and fractionating once with calcium chloride and $20 \%$ $(\mathrm{v} / \mathrm{v})$ ethanol in water this loss was kept below $10 \%$. It was apparent that, with this organism, losses due to incomplete extraction and to enzyme activity were negligible.

Table 1. The precipitation of the nucleoproteins of Sarcina

\section{lutea with cetrimide}

\begin{tabular}{|c|c|c|c|c|c|c|c|}
\hline Cetrimide $(\%)$ & 0 & $0 \cdot 1$ & $0 \cdot 3$ & $0 \cdot 6$ & $1 \cdot 0$ & $1 \cdot 5$ & $2 \cdot 0$ \\
\hline $\begin{array}{l}\text { PNA phosphorus in solution } \\
(\mu \mathrm{g} . / \mathrm{ml} .)\end{array}$ & $71 \cdot 7$ & $44 \cdot 7$ & $1 \cdot 90^{*}$ & $3 \cdot 42$ & $12 \cdot 5$ & $14 \cdot 2$ & $14 \cdot 3$ \\
\hline $\begin{array}{l}\text { DNA phosphorus in solution } \\
(\mu \mathrm{g} . / \mathrm{ml} .)\end{array}$ & $23 \cdot 2$ & $16 \cdot 7$ & & $1 \cdot 37$ & $3 \cdot 60$ & 4.92 & $5 \cdot 15$ \\
\hline
\end{tabular}

* The precipitate was too small to be analysed for PNA and DNA, so only the total phosphorus was determined.

The nucleic acids were separated into DNA and PNA by fractionation with cetrimide, the PNA subsequently being purified by calcium precipitation and the DNA by adsorption with charcoal (Dutta et al. 1953). The recovery of nucleic acids for this stage was $78 \%$, giving an overall recovery of $72 \%$.

\section{Composition of the nucleic acids}

Using the above methods, the DNA and PNA were isolated from batches of organisms which had been grown for 6, 24, 48, 72, 96 and $144 \mathrm{hr}$., and from the strain which had been trained to be resistant to streptomycin, and analysed for their purine and pyrimidine bases. The results are recorded in Table 2.

Table 2. Composition of the nucleic acids of Sarcina lutea

$\begin{array}{lccc}\text { Base } & \text { DNA } & \overbrace{\begin{array}{c}\text { Normal } \\ \text { strain } \\ \text { mole base } / 100 \text { mole nucleotides }\end{array}}^{\begin{array}{c}\text { Streptomycin- } \\ \text { resistant } \\ \text { strain }\end{array}} \\ \text { Guanine } & \overbrace{37 \cdot 1}^{\text {PNA }} & \mathbf{2 8 \cdot 4} & \mathbf{2 9 \cdot 8} \\ \text { Cytosine } & \mathbf{3 7 \cdot 1} & \mathbf{3 2 \cdot 9} & \mathbf{3 4 \cdot 4} \\ \text { Adenine } & \mathbf{1 3 \cdot 4} & \mathbf{1 6 \cdot 7} & \mathbf{1 5 \cdot 7} \\ \text { Thymine } & \mathbf{1 2 \cdot 4} & - & -\overline{20 \cdot 2} \\ \text { Uracil } & - & \mathbf{2 2 \cdot 0} & \end{array}$

For DNA, a recovery of about $3 \cdot 8$ moles of bases per 4 gram-atom of phosphorus was obtained. The composition of samples of DNA isolated from cultures grown for different times did not differ significantly $(c .1 \%)$ and was not greater than the difference between samples isolated from organisms grown for the same time. Also, no significant difference $(c .1 \%)$ was observed between the composition of the DNA from the normal streptomycin-sensitive strain and that of the DNA from the resistant strain. The bases were identified as 
guanine, cytosine, adenine and thymine by their $\boldsymbol{R}_{F}$ values and ultraviolet absorption spectra. No 5-methylcytosine was detected.

For PNA, the presence of the usual four bases was confirmed and a recovery of about 4.0 mole of bases per 4 gram-atom of phosphorus obtained. The PNA from cells grown for different times did not show significant differences, but the PNA from the streptomycin-resistant strain had a different composition from that of PNA from the normal sensitive strain. Statistical analysis of the results showed that this difference was highly significant (e.g. for uracil, $t=5 \cdot 10 ; P<0 \cdot 001)$.

\section{DISCUSSION}

For comparison of the compositions of nucleic acids isolated from different batches of organisms it was important that they should be obtained in good yield, so that any changes in composition would not be due to fractionation during isolation. It has often proved difficult to isolate nucleic acids quantitatively, particularly in the case of PNA (Allen, 1954). In the present work approximately $72 \%$ of the total nucleic acids was isolated. Although this was not as high as was desired, it was concluded that any changes in composition due to fractionation during isolation would be small since the isolation procedure was identical in each case.

The DNA, in common with those from many other bacteria, had a very high proportion of guanine and cytosine to adenine and thymine $((G+C) /$ $(A+T)=2 \cdot 88)$, in fact one of the highest yet recorded, and contained no 5-methylcytosine. The PNA had a larger amount of guanine and cytosine than adenine and uracil. Guanine and cytosine were not present in equimolecular proportions, neither were adenine and uracil, but the ratio of guanine + uracil to adenine + cytosine was very nearly equal to one (1.02). This PNA therefore showed one of the regularities pointed out by Elson \& Chargaff (1954). It has been suggested by these authors that analysis of PNA in situ by mild alkaline hydrolysis would be expected to give more accurate results than analysis of PNA isolated by methods resulting in chemical and enzymic degradation. Such analyses, however, suffer from the disadvantage that the absence of interference by other cell constituents (e.g. DNA) cannot be certain in all organisms. Still more accurate results might be expected from the analysis of PNA which had been isolated by methods in which significant chemical and enzymic degradation had been eliminated. The present method of isolation appeared to approach fairly closely to this ideal in that all operations were carried out at $0^{\circ}$ and near neutral $\mathrm{pH}$; from the recovery of the nucleic acids it was apparent that enzymic degradation was only slight. There was no significant change in the composition of either DNA or PNA during growth of the cultures, a result similar to that obtained for the DNA of Pseudomonas hydrophila by Reddi (1954), and for the PNA of the sea-urchin Paracentrotus lividus by Elson, Gustafson \& Chargaff (1954).

The inability to detect a difference in composition between the DNA from the streptomycin-sensitive strain of Sarcina lutea and that from the resistant strain does not imply that no differences exist. The fact that a transforming 
principle, having the properties of DNA and capable of inducing streptomycinresistance in sensitive strains, has been isolated from streptomycin-resistant strains of Haemophilus influenzae (Alexander \& Leidy, 1953) indicates that the DNA from resistant strains does differ from that from sensitive strains. In our work with the DNA from Sarcina lutea, however, such a difference may have had no effect on the proportions of the bases present, or the difference in proportions may have been too small to detect by the present methods. It has been shown that in Staphylococcus aureus PNA is associated with the production of certain enzymes (Gale \& Folkes, 1955). Since streptomycin-resistant strains would use a number of different enzymes from the normal strain, this may be reflected in a change in the overall composition of the PNA as has been found in this work with Sarcina lutea. This change in composition may have been due either to the synthesis of new PNA associated with new enzyme systems necessary for growth in the presence of streptomycin, or merely to a change in the proportions of the PNA already present in the normal streptomycin-sensitive strain. An increase in the amount of PNA present in streptomycin-resistant strains of Staphylococcus aureus and Haemophilus pertussis compared with that in sensitive strains, has been recorded (Smolens \& Vogt, 1953; Beljanski, 1953).

In the PNA of streptomycin-resistant Sarcina lutea there was an increase in the proportion of guanine and cytosine, and a corresponding decrease in adenine and uracil as compared with PNA from the normal sensitive strain. This result gives some support to the hypothesis (Elson \& Chargaff, 1954) that in part of the PNA, these bases may be associated in a manner similar to those in DNA (Watson \& Crick, 1953). The ratio guanine + uracil to adenine+ cytosine was almost unity $(0.998)$, so that this PNA also showed the same regularity as that from the streptomycin-sensitive strain and those from other organisms.

The authors wish to thank the Medical Research Council for a grant for technical assistance.

\section{REFERENCES}

Alexander, H. E. \& Leidy, G. (1953). Induction of streptomycin-resistance in sensitive Hemophilus influenzae by extracts containing deoxypentosenucleic acid from resistant Hemophilus influenzae. J. exp. Med. 97, 17.

Allen, F. W. (1954). Nucleic acids. Ann. Rev. Biochem. 23, 99.

BELJANSKI, M. (1953). Nucleic acids of bacterial strains resistant to streptomycin and of the same species but sensitive to the antibiotic. Ann. Inst. Pasteur, 85, 463.

Brown, G. L. \& Watson, M. (1953). Heterogeneity of deoxypentosenucleic acids. Nature, Lond. 172, 339.

Caldwell, P. C. \& Hinshelwood, C. (1950). The nucleic acids content of Bact. lactis aerogenes. J. chem. Soc. p. 1415.

Chargaff, E., Crampton, C. F. \& Lipshitz, R. (1953). Separation of calf-thymus deoxypentosenucleic acid into fractions of different composition. Nature, Lond. $172,289$.

Crosbie, R. W., Smellie, R. M. S. \& Davidson, J. N. (1953). Phosphorus compounds in the cell. 5. The composition of the cytoplasmic and nuclear ribonucleic acids of the liver cell. Biochem. J. 54, 287. 
Drsche, Z. (1930). Úber einige neue charakteristische Farbreaktionen der Thymonukleinsäure und eine Mikromethode zur Bestimmung derselben in tierischen Organen mit Hilfe dieser Reaktionen. Mikrochemie, 8, 4.

Dutta, S. K., Jones, A. S. \& Stacey, M. (1953). The separation of deoxypentosenucleic acids and pentosenucleic acids. Biochim. biophys. Acta, 10, 613.

Elson, D. \& Chargaff, E. (1954). Regularities in the composition of pentosenucleic acids. Nature, Lond. 173, 1037.

Elson, D., Gustafson, T. \& Chargaff, E. (1954). The nucleic acids of the seaurchin during embryonic development. J. biol. Chem. 209, 285.

Euler, H. von \& Harn, L. (1946). A new method for the quantitative determination of ribonucleic acid in animal tissues. Svensk kem. Tidskr. 58, 251.

Fish, C. A., Asimor, I. \& Walker, B. S. (1950). Nucleoprotein content during the staphylococcal growth cycle. Proc. Soc. exp. Biol., N.Y. 75, 774 .

Gale, E. F. \& Folkes, J. P. (1955). The assimilation of amino acids by bacteria. 21 . The effect of nucleic acid on the development of certain enzymic activities in disrupted staphylococcal cells. Biochem. J. 59, 675.

Hotchkiss, R. D. (1951). Transfer of penicillin resistance in pneumococei by the deoxyribonucleate derived from resistant cultures. Cold Spr. Harb. Symp. quant. Biol. 16, 457.

JonEs, A. S. (1953). The isolation of bacterial nucleic acids using cetyltrimethylammonium bromide (Cetavlon). Biochim. biophys. Acta, 10, 607.

Jones, A. S., Lee, W. A. \& Peacocke, A. R. (1951). The determination of phosphorus in deoxypentosenucleic acids. J. chem. Soc. p. 623.

Laland, S. G., Overend, W. G., \& Webb, M. (1952). Deoxypentosenucleic acids. Part IV. The properties and composition of the deoxypentosenucleic acids from certain animal, plant, and bacterial sources. J. chem. Soc. p. 3224 .

MA, T. S. \& ZUAZAGA, G. (1942). Micro-Kjeldahl determination of nitrogen: a new indicator and an improved rapid method. Industr. Engng Chem. (Anal.), 14, 280.

Malmgren, B. \& Hedén, C. G. (1947). Studies on the nucleotide metabolism of bacteria. III. The nucleotide metabolism of Gram-negative bacteria. Acta path. microbiol. scand. 24, 448. IV. The nucleotide metabolism of Grampositive bacteria. ibid. 472 .

Mitchell, P. \& Moyle, J. (1954). The Gram reaction and cell composition: nucleic acids and other phosphate fractions. J. gen. Microbiol. 10, 533.

RedDi, K. K. (1954). Deoxypentosenucleic acid from Pseudomonas hydrophila. Biochim. biophys. Acta, 15, 585.

Schmidt, G. \& Thannhauser, S. J. (1945). A method for the determination of deoxyribonucleic acid, ribonucleic acid and phosphoproteins in animal tissues. J. biol. Chem. 161, 83.

Schneider, W. C. (1945). Phosphorus compounds in animal tissues. I. Extraction and estimation of deoxypentose-nucleic acid and pentosenucleic acid. J. biol. Chem. 161, 293.

SevaG, M. G. (1934). Eine neue physikalische Enteiweissungsmethode zur Darstellung biologisch wirksamer Substanzen. Biochem. Z. 273, 419.

Smolens, J. \& Vogt, A. B. (1953). The antibiotic resistance and nucleic acid content of bacteria. J. Bact. 66, 140.

Watson, J. D. \& Crick, F. H. C. (1953). A structure for deoxyribose nucleic acid. Nature, Lond. 171, 737.

Wyatt, G. R. (1951). Purine and pyrimidine composition of deoxypentosenucleic acids. Biochem. J., 48, 584. 